\title{
ANALISIS FAKTOR KINERJA KADER POSYANDU MENUJU REVITALISASI POSYANDU DI WILAYAH PUSKESMAS SINGAPARNA DESA CIKUNIR 2013
}

\author{
Oleh: \\ Lilis Lisnawati, S.ST, M.Keb
}

\begin{abstract}
A. Abstrak
Kegiatan revitalisasi posyandu pada dasarnya meliputi seluruh posyandu dengan perhatian utamanya pada posyandu yang sudah tidak aktif/rendah stratanya (pratama dan madya) sesuai kebutuhan, posyandu yang berada di daerah yang sebagian besar penduduknya tergolong miskin, serta adanya dukungan materi dan non materi dari tokoh masyarakat setempat dalam menunjang pelaksanaan kegiatan posyandu. Dukungan masyarakat sangat penting karena komitmen dan dukungan mereka sangat menentukan keberhasilan dan kesinambungan kegiatan posyandu (Depkes RI, 1999). Kontribusi posyandu dalam meningkatkan kesehatan bayi dan anak balita sangat besar, namun sampai saat ini kualitas pelayanan posyandu masih perlu ditingkatkan.
\end{abstract}

Terjadinya penurunan kunjungan mengindikasikan kecenderungan masyarakat menggunakan layanan kesehatan hanya saat membutuhkan misalnya saat mereka sakit, bukan untuk mendapatkan pelayanan monitoring atatu meningkatkan pengetahuan kesehatan dan gizi seperti yang diberikan di Posyandu. Pergeseran kebutuhan menjadi penyebab Posyandu makin ditinggalkan. Semakin banyak ibu-ibu yang membawa balitanya ke fasilitas kesehatan atau praktik dokter swasta untuk imunisasi. Hasil wawancara dengna Bidan juga mengindikasikan ada beberapa kader yang tidak aktif lagi di posyandu karena kesibukan di luar kegiatan posyandu. Kedua kondisi tersebut, berdampak pada jumlah kunjungan posyandu yang variatif rendah dengan rasio sasaran posyandu (Ibu hamil, menyusui, bayi, balita) yaitu sekitar 45\%. Fenomena di atas mendorong dilaksanakannya penelitian ini dengan tujuan untuk melihat bagaimana kinerja kader posyandu. Asumsi yang digunakan oleh peneliti ini adalah kinerja kader yang semakin baik akan mendorong kunjungan paea ibu ke posyandu sebagai output berhasilnya proses revitalisasi posyandu.

Penelitian ini berbentuk explanatory research dengan desain penelitian studi kuantitatif, metode survey. Dalam penelitian ini terdapat dua peubah, yakni peubah bebas dan peubah terikat. Peubah bebas terdiri dari karakteristik kader terdiri dari: usia, jumlah anggota keluarga, tingkat pendidikan, status perkawinan, adanya anak balita, status pekerjaan, dan lama menjadi kader. Faktor pendorong mencakup motivasi menjadi kader, insentif yang diterima. Kinerja kader posyandu mencakup tanggung jawab dan persiapan posyandu oleh kader

Sebagian besar kader posyandu termasuk kategori usia produktif, pendidikan Sekolah Dasar dan Menengah, sebagai besar adalah berasal dari keluarga kecil yaitu <4, dan telah menikah dan umumnya tidak mempunyai balita yang diasuh. Rata-rata lama menjadi kader > 36 bulan, motivasi kader adalah sebagai pengabdian pada masyarakat, Semua kader mendapatkan insentif dari pihak Puskesmas, umumnya memiliki dukungan posisitif dari suami dan keluarga. Adapun sebagai upaya untuk mempertahankan bahkan meningkatkan kinerja kader posyandu perlu dipertimbangkan pemberian insentif yang lebih layak. Insentif dapat diusahakan dari iuran para ibu yang berkunjung ke posyandu atau dengan mengalokasikan dari kas desa.

\section{Kata Kunci: Kinerja Kader Posyandu, Revitalisasi Posyandu, Posyandu}




\section{B. Latar Belakang}

Pemerintah telah menetapkan berbagai kebijakan di bidang kesehatan. Salah satunya adalah kebijakan untuk merevitalisasi kembali posyandu dalam rangka menuju Indonesia Sehat 2010. Posyandu merupakan sistem pelayanan yang dipadukan antara satu program dengan program lainnya yang merupakan forum komunikasi pelayanan terpadu dan dinamis seperti halnya program $\mathrm{KB}$ dengan kesehatan atau berbagai program lainnya yang berkaitan dengan kegiatan masyarakat (BKKBN, 1989). Pelayanan yang diberikan di posyandu bersifat terpadu, hal ini bertujuan untuk memberikan kemudahan dan keuntungan bagi masyarakat karena di posyandu tersebut masyarakat dapat memperolah pelayanan lengkap pada waktu dan tempat yang sama (Depkes RI, 1990). Posyandu dipandang sangat bermanfaat bagi masyarakat namun keberadaannya di masyarakat kurang berjalan dengan baik, oleh karena itu pemerintah mengadakan revitalisasi posyandu.

Revitalisasi posyandu merupakan upaya pemberdayaan posyandu untuk mengurangi dampak dari krisis ekonomi terhadap penurunan status gizi dan kesehatan ibu dan anak. Kegiatan ini juga bertujuan untuk meningkatkan pemberdayaan masyarakat dalam menunjang upaya mempertahankan dan meningkatkan status gizi serta kesehatan ibu dan anak melalui peningkatan kemampuan kader, manajemen dan fungsi posyandu (Depdagri, 1999).

Kegiatan revitalisasi posyandu pada dasarnya meliputi seluruh posyandu dengan perhatian utamanya pada posyandu yang sudah tidak aktif/rendah stratanya (pratama dan madya) sesuai kebutuhan, posyandu yang berada di daerah yang sebagian besar penduduknya tergolong miskin, serta adanya dukungan materi dan non materi dari tokoh masyarakat setempat dalam menunjang pelaksanaan kegiatan posyandu. Dukungan masyarakat sangat penting karena komitmen dan dukungan mereka sangat menentukan keberhasilan dan kesinambungan kegiatan posyandu (Depkes RI, 1999). Kontribusi posyandu dalam meningkatkan kesehatan bayi dan anak balita sangat besar, namun sampai saat ini kualitas pelayanan posyandu masih perlu ditingkatkan.

Penelitian yang dilakukan oleh Puja, telah diketahui bahwa keberlangsungan Posyandu dipengaruhi oleh banyak faktor. Faktor tersebut terbagun dari aspek internal pelaksana maupun eksternal posyandu yaitu kinerja kader dan sasaran (komunitas). Faktor dari dalam Posyandu berupa karakteristik kader dan faktor pendorong. Sedangkan faktor dari luar Posyandu berupa tingkat kinerja kader dalam persiapan dan pelaksanaan posyandu, serta kondisi masyarakat meliputi: tingkat pendidikan, sosial ekonomi masyarakat serta jumlah balita.

Berdasarkan data Dinas Kesehatan Kab. Tasikmalaya tahun 2010 diketahui bahwa kecamatan Singaparna memiliki 2 puskesmas yaitu Puskesmas Singaparna (70 posyandu) dan Puskesmas Tinewati (12 posyandu). Jumlah kader aktif 236 orang dengan ratio posyandu dan kader adalah 3 artinya dalam setiap posyandu rata-rata memiliki 3 kader. Adapun Desa Cikunir sebagai Desa Binaan STIKes Respati Tasikmalaya berada dibawah binaan kesehatan Puskesmas Singaparna. Jumlah Pusyandu jumlah di Desa Cikunir diketahui sebanyak 13 posyandu dan memiliki kader 39 orang dan kader aktif 20 orang.

Berdasarkan informasi yang diperoleh dari Bidan Desa Cikunir dan pihak puskesmas yang menunjukkan ada indikasi penurunan jumlah kunjungan ibu-ibu bayi dan balita ke posyandu. Terjadinya penurunan kunjungan mengindikasikan kecenderungan masyarakat menggunakan layanan kesehatan hanya saat membutuhkan misalnya saat mereka sakit, 
bukan untuk mendapatkan pelayanan monitoring atatu meningkatkan pengetahuan kesehatan dan gizi seperti yang diberikan di Posyandu. Pergeseran kebutuhan menjadi penyebab Posyandu makin ditinggalkan. Semakin banyak ibuibu yang membawa balitanya ke fasilitas kesehatan atau praktik dokter swasta untuk imunisasi. Hasil wawancara dengna Bidan juga mengindikasikan ada beberapa kader yang tidak aktif lagi di posyandu karena kesibukan di luar kegiatan posyandu. Kedua kondisi tersebut, berdampak pada

\section{Metode Penelitian}

Populasi dalam penelitian ini adalah seluruh kader posyandu yang ada di Desa Cikunir sejumlah 40 kader. Sampel bersifat total sampling. Penelitian dilaksanakan selama 3 bulan mencakup kegiatan penyusunan proposal, penyusunan instrument, pengambilan data, analisis data, dan penulisan laporan.

Penelitian ini berbentuk explanatory research dengan desain penelitian studi kuantitatif, metode survey. Dalam penelitian ini terdapat dua peubah, yakni peubah bebas dan peubah terikat. Peubah bebas terdiri dari karakteristik kader terdiri dari: usia, jumlah anggota keluarga, tingkat pendidikan, status perkawinan, adanya anak balita, status pekerjaan, dan lama menjadi kader. Faktor pendorong mencakup motivasi menjadi kader, insentif yang diterima. Kinerja kader posyandu mencakup tanggung jawab dan persiapan posyandu oleh kader.

Pengolahan data dibagi menjadi dua yakni statistika deskriptif dan statistika induktif (inferensial). untuk menganalisis hubungan antar peubah mengggunakan Analisis korelasi Spearman. jumlah kunjungan posyandu yang variatif rendah dengan rasio sasaran posyandu (Ibu hamil, menyusui, bayi, balita) yaitu sekitar $45 \%$.

Fenomena di atas mendorong dilaksanakannya penelitian ini dengan tujuan untuk melihat bagaimana kinerja kader posyandu. Asumsi yang digunakan oleh peneliti ini adalah kinerja kader yang semakin baik akan mendorong kunjungan paea ibu ke posyandu sebagai output berhasilnya proses revitalisasi posyandu.

\section{Hasil penelitian}

\section{a. Karakteristik kader}

Tingkat pendidikan kader ksehatan Ds. Cikunir berdasarkan jenjang pendidikan terakhirnya dapat dilihat dari gambar 3.1

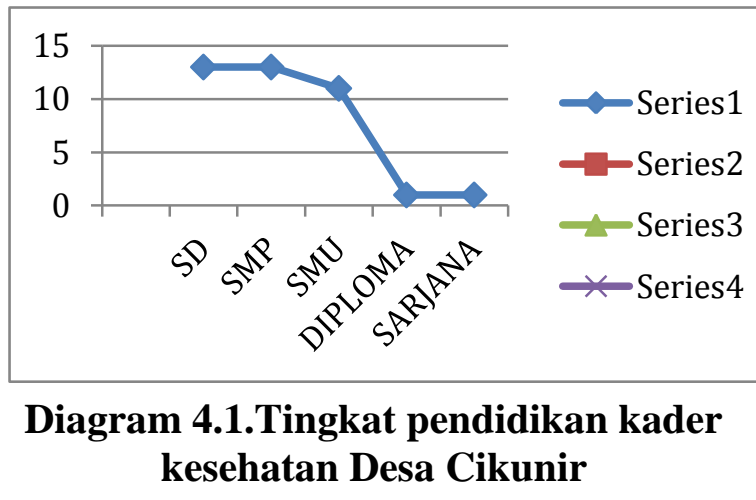

Berdasarkan gambar. 3.1 diketahui bahwa dari 40 kader yang ada di Desa Cikunir didominasi jenjang pendidikan Sekolah Dasar (SD). Adapun sebaran yang kedua berada di jenjang pendidikan SMP dan diikuti SMA. Sedangkan sebagian kecil tersebar di jenjang pendidikan Diploma dan Sarjana. 
Tabel 4.1 Distribusi Frekuensi Tingkat Pendidikan Kader Ds. Cikunir

\begin{tabular}{|c|c|c|}
\hline $\begin{array}{c}\text { Tingkat } \\
\text { Pendidika } \\
\text { n }\end{array}$ & $\begin{array}{c}\text { Jumla } \\
\text { h }\end{array}$ & $\begin{array}{c}\text { Presentas } \\
\mathbf{e}(\boldsymbol{\%})\end{array}$ \\
\hline SD & 13 & $32.5 \%$ \\
\hline SMP & 13 & $32.5 \%$ \\
\hline SMA & 12 & $30.0 \%$ \\
\hline Diploma 2 & 1 & $2.5 \%$ \\
\hline Sarjana & 1 & $2.5 \%$ \\
\hline Jumlah & $\mathbf{4 0}$ & $\mathbf{1 0 0}$ \\
\hline
\end{tabular}

( Sumber: Hasil Penelitian 2014)

Adapun karakteristik berdasarkan usia kader, dapat dilihat pada table 4.2

Tabel 4.2 Distribusi Frekuensi rentang Usia Kader Ds. Cikunir

\begin{tabular}{|c|c|c|}
\hline Usia & Jumlah & $\begin{array}{c}\text { Presentase } \\
(\boldsymbol{\%})\end{array}$ \\
\hline$<25$ & 3 & $7.5 \%$ \\
\hline $\begin{array}{c}25- \\
35\end{array}$ & 13 & $32.5 \%$ \\
\hline$>35$ & 14 & $60.0 \%$ \\
\hline
\end{tabular}

( Sumber: Hasil Penelitian 2014)

Berdasarkan tabel 4.2 diketahui bahwa rentang usia para kader di Ds. Cikunir tersebar dalam berbagai rentang usia. Adapun rentang usia para kader mayoritas berada pada rentang usia produktif.

Tabel 4.3 Distribusi Frekuensi Jenis Pekerjaan Kader Ds.

\begin{tabular}{|c|c|r|}
\multicolumn{3}{|c}{ Cikunir } \\
\hline $\begin{array}{c}\text { Jenis } \\
\text { Pekerjaa } \\
\text { n }\end{array}$ & $\begin{array}{c}\text { Ju } \\
\text { mlah }\end{array}$ & $\begin{array}{r}\text { Prese } \\
\text { ntase }(\%)\end{array}$ \\
\hline IRT & 38 & $95 \%$ \\
\hline Guru & 1 & $2.5 \%$ \\
\hline $\begin{array}{c}\text { Pedag } \\
\text { ang }\end{array}$ & 1 & $2.5 \%$ \\
\hline
\end{tabular}

( Sumber: Hasil Penelitian 2014)

Berdasarkan tabel 4.3 diketahui bahwa mayoritas jenis pekerjaan para kader di Ds. Cikunir adalah Ibu Rumah Tangga (IRT).

Subvariabel yang dianalisis dalam menggambarkan kinerja Kader dalam revitalisasi posyandu meliputi: lama pengabdian, tujuan menjadi kader, insentif, gambaran kinerja kader.

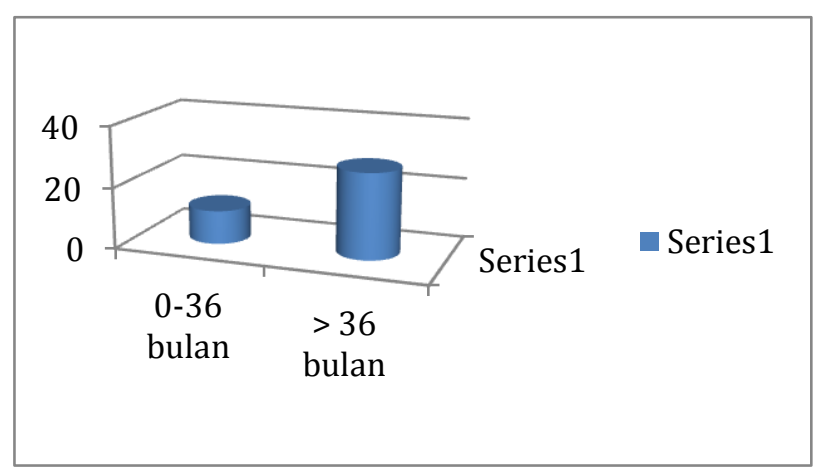

\section{Diagram 3.2 Deskripsi Lama Pengabdian}

Adapun untuk lebih jelasnya berikut distribusi frekuensi dari sub variabel lama pengabdian kader Ds. Cikunir.

Tabel 4.4 Distribusi Frekuensi Lama Pengabdian Kader Ds. Cikunir

\begin{tabular}{|c|c|c|}
\hline $\begin{array}{c}\text { Lama } \\
\text { Pengabdian }\end{array}$ & Jumlah & $\begin{array}{c}\text { Presentase } \\
(\boldsymbol{\%})\end{array}$ \\
\hline$<36$ bulan & 10 & $25 \%$ \\
\hline$>36$ bulan & 30 & $75 \%$ \\
\hline
\end{tabular}

\section{( Sumber: Hasil Penelitian 2014)}

Berdasarkan tabel 4.4 diketahui bahwa lama pengabdian kader sebagian besar lebih dari 36 bulan (> 3 tahun) lama pengabdian menjadi kader Ds. Cikunir.

a. Faktor Pendorong Motivasi menjadi kader

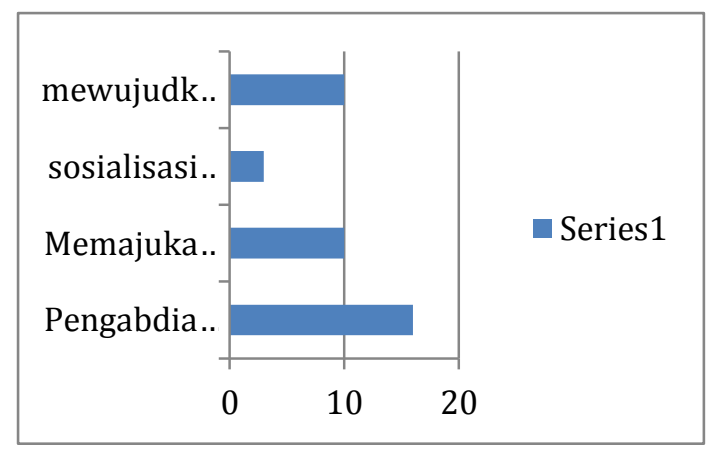




\section{Diagram 3.3 Deskripsi Alasan Menjadi Kader}

Berdasarkan hasil wawancara yang dilakukan pada 40 kader Desa Cikunir, setiap jawaban responden dapat dikelompokkan menjadi 4 kategori motivasi responden untuk menjadi kader diantaranya: Mewujudkan kesehatan masyarakat, Sosialisasi Masyarakat, Memajukan posyandu, dan Pengabdian

\section{Kepuasan Insentif}

Tabel. 4.5 Distribusi Frekuensi Kepuasan Insentif Kader Ds.

Cikunir

\begin{tabular}{|c|c|c|}
\hline Kepuasan Insentif & Jumlah & Presentase (\%) \\
\hline Memuaskan & 12 & $30,0 \%$ \\
\hline Cukup Memuaskan & 13 & $32.5 \%$ \\
\hline Kurang Memuaskan & 15 & $37.5 \%$ \\
\hline
\end{tabular}

\section{( Sumber: Hasil Penelitian 2014)}

Berdasarkan tabel. 4.5 diketahui bahwa 37.5\% kader menilai insentif yang diterima kurang memuaskan bila dibandingkan dengan tugas dan tanggung jawabnya di posyandu.

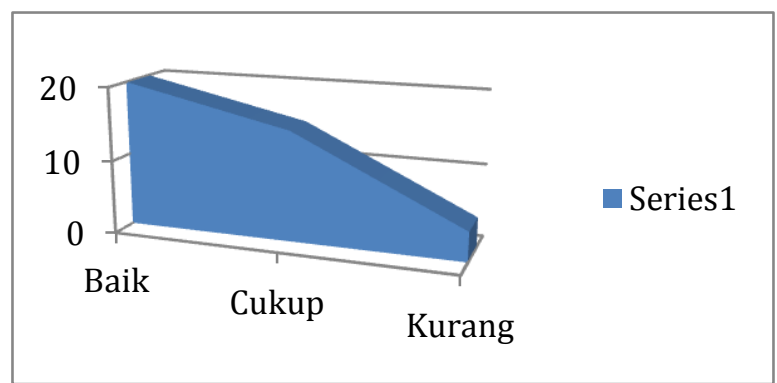

Berdasarkan diagram 4.4 diketahui bahwa kinerja kader berdasarkan b. Kinerja Kader Tanggung Jawab

Diagram 4. 4 Deskripsi kinerja kader (Tanggung Jawab)

komponen tanggung jawab adalah $50 \%$ diantaranya kader memiliki tanggung jawab yang baik dalam melaksanakan tugasnya di posyandu.

Persiapan Posyandu

Tabel. 4.6

Distribusi Frekuensi Kinerja Kader (Persiapan Posyandu) Kader Ds.

Cikunir

\begin{tabular}{|c|c|c|}
\hline Kepuasan Insentif & Jumlah & Presentase (\%) \\
\hline Baik & 15 & $37.5 \%$ \\
\hline Cukup & 12 & $30.5 \%$ \\
\hline Kurang & 13 & $32.5 \%$ \\
\hline
\end{tabular}

( Sumber: Hasil Penelitian 2014)

Berdasarkan tabel 4.6 diketahui $37.5 \%$ diantaranya kader baik dalam bahwa kinerja kader berdasarkan melaksanakan persiapan posyandu. komponen tanggung jawab adalah

\section{E. Pembahasan}

Kegiatan posyandu sangat tergantung pada kader posyandu, keberadaan kader posyandu dibutuhkan 
sebagai salah satu system

penyelenggaraan pelayanan kebutuhan

\section{a. Karakteristik Kader}

Kader posyandu merupakan ujung tombak pelayanan kesehatan yang merupakan perpanjangan tangan puskesmas. Berdasarkan karakter kebaradaan kader posyandu di Desa Cikunir diketahui bahwa 58\% berdasarkan usia kader berada pada rentang usia 26-45 tahun, hal itu menunjukkan berada pada rentang usia produktif kader. Pada kelompok usia produktif ini dapat lebh mengalokasikan waktunya untuk aktif dalam kegiatan

Berdasarkan tingkat pendidikan kader tamatan SD. SLTP dan SLTA, hal ini berarti tingkat pendidikan adalah termasuk kategori pendidikan dasar. Kemampuan ini sejalan pula dengan salahsatu dari 7 kriteria yang harus Nulis kesehatan dasar.

posyandu. Menurut Havigurst dan Robert usia kader adalah termasuk dewasa Madya (usia pertengan 30-60 tahun) dengan tugas pengembangan pada usia ini adalah mengembangkan kegiatan mengisi waktu senggang untuk orang dewasa denagn adanaya perubahan minat dalam tanggungjawab warga negara dan sosial serta mengembangkan niat pada waktu luang yang berorientasi pada kedewasaan pada tempat kegiatan yang berorientasi pada keluarga.

dipenuhi oleh Seorang kader seperti tercantum dalam Instruksi Menteri Dalam Negeri No.09 Tahun 1990 tentang peningkatan pembinaan mutu posyandu, yaitu dapat membca dan me

Tabel. 5.1 Sebaran Karakteristik Kader Posyandu

\begin{tabular}{|c|c|c|c|}
\hline Peubah & $\%$ & Peubah & $\%$ \\
\hline \multicolumn{4}{|l|}{ Usia kader } \\
\hline$<25$ & $7.5 \%$ & \multirow{2}{*}{$\begin{array}{l}\text { Ada anak yang harus } \\
\text { diasuh kader }\end{array}$} & \\
\hline $25-35$ & $32.5 \%$ & & $65.0 \%$ \\
\hline$>35$ & $60,0 \%$ & Tidak mempunyai & $35.0 \%$ \\
\hline Tingkat & & balita & \\
\hline Pendidikan & $32.5 \%$ & Mempunyai balita & $45.0 \%$ \\
\hline $\mathrm{SD}$ & $32.5 \%$ & Jumlah anggota & $30.0 \%$ \\
\hline SMP & $30.0 \%$ & keluarga & $25.0 \%$ \\
\hline SMA & $5.0 \%$ & $<4$ orang & \\
\hline Diploma & $5.0 \%$ & $5-6$ orang & $95.0 \%$ \\
\hline Sarjana & & 7 orang & $5.0 \%$ \\
\hline Status & $0.0 \%$ & Status pekerjaan & \\
\hline Perkawinan & $92.0 \%$ & Bekerja & $25.0 \%$ \\
\hline Belum & $8.0 \%$ & Tidak Bekerja & $75.0 \%$ \\
\hline Menikah & & Lama menjadi kader & \\
\hline Menikah & & $<36$ bulan & \\
\hline Janda & & $>36$ bulan & \\
\hline
\end{tabular}

Selanjutnya berdasarkan lama pengabdian Seorang kader posyandu kader di Ds. Cikunir, 30 orang $(75 \%)$ diperoleh data bawah dari 40 orang diantaranya telah mengabdikan dirinya menjadi kader $>36$ bulan. Data tersebut 
menunjukkan bahwa kader sudah cukup berpengalaman dalam mengelola posyandu yang mengindikasikan adanya dukungan dari keluarga.

\section{b. Motivasi menjadi kader}

Berdasarkan hasil wawancara yang dilakukan pada 40 kader Desa Cikunir, setiap jawaban responden dapat dikelompokkan menjadi 4 kategori tujuan diantaranya: Mewujudkan kesehatan masyarakat, Sosialisasi Masayarakat, Memajukan posyandu, dan Pengabdian Masyarakat.

Adapun dari 4 kategori jawaban responden 17 kader $(42.5 \%)$ diantaranya adalah sebagai bentuk pengabdian pada masyarakat dan 3 kader $(7.5 \%)$ menyatakan alasan menjadi kader sebagai bentuk bersosialisasi dengan masyarakat.

Berdasarkan data hasil penelitian tersebut diketahui bahwa hampir separuh dari kader posyandu dari responden berjiwa sosial kemasyarakatan. Hal ini sejalan dengan salah satu dari kriteria yang harus dipenuhi oleh Seorang kader seperti tercantum dalam Instruksi Menteri Dalam Negeri No. 09 Tahun 1990 tentang Peningkatan Pembinaan Mutu Posyandu, yakni: (1) Dapat membaca dan menulis, (2) Berjiwa sosial dan mau bekerjasama secara sukarelawan (3) Mengetahui adat istiadat serta kebiasaan masyarakat, mempunyai waktu yang cukup, (5) Bertempat tinggal di wilayah Posyandu (5) Berpenampilan ramah dan simpatik dan (\&) Diterima masyarakat setempat. Adapun menurut Vitriah mengungkakan salah satu factor individu yang secara signifikan memberikan kontribuso terhadap kinerja adalah motivasi.

Menurut analisa peneliti berdasarkan hasil wawancara pada responden hal yang melatarbelakangi keinginan untuk menjadi responden diantaranya adalah pendidikan.
Menurut Abdul Rahman (2008) pendidikan adalah segala upaya yang direncanakan untuk mempengaruhi oran lain, baik individu atau masyarakat sehingga mereka melakukan apa yang diharapkan oleh pelaku pendidikan. Tingkat pendidikan yang cukup merupakan dasar pengembangan wawasan serta saran untuk memudahkan seseorang untuk menerima pengetahuan, sikap dan perilaku baru.

$$
\text { Menurut Markusi }
$$

pendidikan adalah segala sesuatu yang dilakukan secara sadar untuk membina kepribadian, mengembangkan kemampuan manusia baik jasmani maupun rohani yang berlangsung seumur hidup maupun di luar sekolah.

Adapun hasil penilaian karakteristik dari responden yang dilakukan oleh peneliti umumnya tingkat jenjang pendidikan mayoritas tersebar di tingkat SD, SMP dan SMA dengan total presentasi $95 \%$ sedangkan sisanya tersebar di jenjang pendidikan Diploma dan Sarjana.

Berdasarkan uraian di atas, maka menurut peneliti secara sederhana pendidikan dapat diartikan sebagai usaha manusia untuk membina kepribadiannya sesuai dengan kondisi primitifnya atau berlangsung proses pendidikan. Secara umum pendidikan sangat berpengaruh terhadap pengetahuan dan sikap masyarakat. Pendidikan merupakan dasar dalam pengembangan atau pembangunan wawasan seseorang, untuk menerima pengetahuan dan perilaku baru. Seorang kader dengan pendidikan yang lebih tinggi diharapkan mempunyai perilaku keaktifan dalam program kegiatan posyandu.

Menurut analisis peneliti hal yang melatarbelakangi kesediaan untuk menjadi kader juga dilatarbelakangi oleh adanya dukungan keluarga. Keluarga sebagai tempat utama individu belajar nilai-nilai, norma, dan tempat membina 
hubungan system, keluarga merupakan supra system, dan individu (anggota keluarga) merupakan sub system masyarakat. Friedman (2001), menyatakan salah satu fungsi keluarga mengasuh, cinta kasih, kehangatan, saling menerima, saling mendukung antar anggota keluarga. Setiap anggota yang mendapatkan kasih sayang dan dukungan dari anggota yang lain maka kemampuan untuk memperbaiki kasihsayang akan meningkat yang pada akhirnya tercipta hubungan yang hangat dan saling mendukung.

Berdasarkan hasil analisis di lokasi penelitian sebagain besar dari kader posyandu adalah generasi penerus yang sebelumnya sudah aktif dalam kegiatan posyandu dan sebagai kecil adalah kader-kader baru yang mendapatkan dukungan dari suami untuk menjadikannya sebagai kader posyandu.

Dengan demikian adanya dukungan keluarga dan suami terhadap seseorang menjadi motor yang cukup efektif untuk menggerakkan seseorang berpartisipasi di lingkungan baru sekalipun menuntut pembagian waktu dan menambah beban tanggung jawabnya disamping kewajiban utamanya dalam rumah tangga dan keluarga.

Hasil penelitian ini menurut Khotimah (2002), bahwa akibat kurangnya peran bidan desa sebagai petugas kesehatan di desa maupun dari institusi terkait, mengakibatkan turunnya aktivitas posyandu. Kenyataan ini mengakibatkan banyakanya posyandu yang tidak aktif dan atau tidak mengalami perkembangan. Hal ini berdampak pada adanya sikap pro dan kontra terhadap kelangsungan posyandu, sebagian masyarakat menilai posyandu akan sulit untuk bertahan dan kelompok masyarakat pro menilai bahwa posyandu masih sangat dibutuhkan dan masih banyak cara yang dapat dilaksanakan untuk mengaktifkan kembali (revitalisasi) kegiatan posyandu.

Kondisi ini ditemukan di lapangan dimana masyarakat terbagi menjadi 2 kelompok yaitu kelompok pro yaitu yang aktif dan berpartisipasi dalam posyandu dan kelompok kontra yang tidak berpartisipasi baik dalam penyelenggarana kegiatan posyandu di lingkungan masyarakat maupun kunjungannya. Adanya keberadaan masyarakat yang pro ditunjukkan dengan partisipasinya untuk menjadi kader posyandu yang mempunyai niat tulus dan ikhlas untuk mempertahankan dan memajukan kelangsungan posyandu. Adapun keberadaan kader posyandu perlu mendapatkan support dari petugas kesehatan khususnya Bidan Desa baik secara keilmuan, kesempakatan berkarya dan pengembangan kesejahteraan agar mereka mampu melaksanakan kinerja dengan optimal sesuai dengan tugas dan kewajibannya.

Dengan demikian dapat disimpulkan bahwa terdapat faktor pendidikan, dukungan keluarga dan dukungan dari Bidan Desa, yang melatarbelakangi tujuan para responden untuk mengabdi menjadi sorang kader posyandu.

Berdasarkan tabel. 4.5 diketahui bahwa seluruh kade rmendapatkan insentif sebagai bentuk penghargaan aparat desa terhadap kinerjanya di posyandu, akan tetapi berdasarkan penggalian informasi langsung dari respondesn diketahui $37.5 \%$ kader menilai bahwa insentif yang diterima dari tugasnya dalam pengelolaan posyandu kurang memuaskan. Meskipun pekerjaan kader adalah sebagai relawan atau bersifat filantopi namun para kader masih mengharapkan adanya insentif yang memadai. Jumlah insentif yang selama ini dianggap kurang memadai, menjadi pertimbangan untuk diusulkan kenaikan insentifnya. Hasil wawancara 
mendalam juga mengindikasikan insentif yang diterima masih sangat kurang bila dibandingkan banyaknya kerja yang diakukan.

Penghargaan atau reward ini sangat penting untuk menunjang peningkatan kinerja. Sama hal nya dengan petugas posyandu yang sebagian besar adalah kader sukarela dari masyarakat, sangat memerlukan penghargaan atas pekerjaan yang sudah dilakukannya. Insentif merupakan salah satu bentuk penghargaan pada kader dalam bentuk uang. Adanya penghargaan ini diharapkan menjadi motivasi bagi kader untuk semangat dalam menjalankan tugas fungsinya di posyandu.

Menurut P.Siagian (2005) insentif merupakan daya tarik orang datang dna tinggal dalam suatu organisasi yang artinya sistem pengkajian dan pelaksanaan perlu dikembangkan sedemikian rupa agar sistem perangsang adil dan berbuat lebih baik terhadap pekerjaan yang dilakukan.

Imbalan yang baik adalah sistem yang mampu menjamin kepuasan para anggota, memelihara dan memperkerjakan orang dengan berbagai sikap perilaku positif dan produktif bagi kepentingan organisasi misalnya pergerakan, kemampuan, pengetahuan, keterampilan dan waktu tenaga para pekerja (Sondang P Siagian, 2001)

Hasil penenlian ini sejalan dengan hasil penelitian Heri Sutadi dkk (2006) mengemukakan bahwa kader posyandu juga mengharapkan ada honor untuk setiap pertemuan karena kegiatan kader pantas diimbali jasa.

Berdasarkan uraian di atas maka menurut peneliti kader sebagai tenaga sukarela yang berasal dari masyarakat, mendapat kepercayaan dari masyarakat setempat dan mendapat latihan serta merasa terpanggil untuk melaksanakan, memelihara, dan mengembangkan kegiatan posyandu. Oleh karena itu kader perlu mendapatkan pembinaan dan penghargaan. Sejalan dengan tugas dan fungsi kader sudah selayaknya pemerintah lebih menghargai peran kader posyandu dengan memberikan insentif finansial yang memadai.

Adapun dari 4 kategori jawaban responden 17 kader (42.5\%) diantaranya adalah sebagai bentuk pengabdian pada masyarakat dan 3 kader (7.5\%) menyatakan alasan menjadi kader sebagai bentuk bersosialisasi dengan masyarakat.

Tabel.5.2 Sebaran Faktor-faktor Pendorong kinerja Kader Posyandu

\begin{tabular}{lclc}
\hline Peubah & $\%$ & Peubah & \multicolumn{2}{c}{$\%$} \\
Motivasi kader & & Ada anak yang harus diasuh & \\
Kesehatan & $15.0 \%$ & kader & $65.0 \%$ \\
Masyarakat & $7.5 \%$ & Tidak mempunyai balita & $35.0 \%$ \\
Sosialisasi & $35,0 \%$ & Mempunyai balita & \\
Masyarakat & $42.5 \%$ & Jumlah anggota keluarga & $45.0 \%$ \\
Memajukan & & $<4$ orang & $30.0 \%$ \\
$\quad$ Posyandu & $100.0 \%$ & $5-6$ orang & $25.0 \%$ \\
Pengabdian & $0.0 \%$ & 7 orang & \\
Masyarakat & & Status pekerjaan & $95.0 \%$ \\
Insentif & & Bekerja & $5.0 \%$ \\
Ada & & Tidak Bekerja & \\
Tidak Ada & & Lama menjadi kader & $25.0 \%$ \\
& & $<36$ bulan & $75.0 \%$ \\
\hline
\end{tabular}


Kinerja kader Menurut K-STATE, penilaian kinerja adalah proses yang penting untuk meningkatkan efektivitas penyuluh. Kualitas kerja dan produktivitas kinerja penyuluh dalam hal ini adalah kader dapat didefinisikan oleh delapan elemen yang terdiri dari kualitas pekerjaan, ketergantungan, jadwal kerja, kebiasaan kerja, alokasi kerja, ketenagaan, organisasi kerja dan kepuasan pelanggan.

Berdasarkan konsep kerja jika dianalisis maka konsep yang dibangun tentang kinerja adalah hasil kerja secara kualitas dan kuantitas yang dicapai oleh seseorang kader dalam melaksanakan tugasnya sesuai dengan tanggung jawab yang diberikan kepadanya.

Adapun hasil studi Thach, Ismail, Uli dan Idris mengungkapkan empat faktor individu yang secara signifikan memberikan kontribusi terhadap kinerja penyuluh, yaitu keterampilan sosial, keterampilan pelaksanaan program, motivasi, dan keterampilan perencanaan program.

Hasil penelitian Mastuti menunjukkan bahwa ada hubungan jenjang pelatihan, c. Hubungan antar peubah

Hasil analisis korelasi mengindikasikan adanya hubungan anatara lama menjadi kader dengan kinerja kader, semakin lama menjadi kader kinerjanya cenderung semakin tinggi. Hal ini sejalan dengan penelitian Long dan Swortzel serta penelitian Rohmani dimana terdapat hubungan proses pemilihan menjadi kader dan keikutsertaan kader dalam organisasi lain dengan kelangsungan kader.

Berdasarkan diagram 4.5 diketahui bahwa kinerja kader berdasarkan komponen tanggung jawab adalah 50\% dinilai memiliki tanggung jawab yang baik dalam melaksanakan tugasnya di posyandu. Hal ini sangat tampak pada kemampuannya dalam mempersiapkan kegiatan posyandu, yaitu berdasarkan tabel 4.6 diketahui bahwa kinerja kader $37.5 \%$ melaksanakan persiapan posyandu dengan baik.

Adapun jika dihubungkan dengan permasalahan penelitian in iyakni semakin rendahnya tingkat kunjungan ibu tidak sejalan dengan kinerja yang dirasakan oleh kader yang merasa puas dengan kinerjanya. Hasil ini sejalan dengan studi Long dan Swortzel yang menyatakan sebagian besar penyuluh merasa kinerjanya sudah baik. Studi aidha juga menunjukkan bahwa kinerja kader posyandu juga tergolong sudah baik.

positif antara kinerja dengan lama kerja. Tidak ada hubungan yang nyata antara karakteristik internal kader posyandu dengan kinerja. Hasil ini sejalan dengan temuan Vitriah yang menyatakan tidak terdapat hubungan umur dan pendidikan dengan kelangsungan kader, akan tetapi berbeda dengan penelitian Long dan Swortzel

dimana terdapat hubungan positif antara kinerja dengan usia.

\begin{tabular}{|lc|}
\hline \multicolumn{1}{|c|}{ Peubah } & Kinerja kader \\
\hline Usia & 0,208 \\
Tingkat pendidikan & 0.085 \\
Jumlah anggota & 0.219 \\
Lama menjadi kader & $\mathbf{0 . 3 7 5}^{*}$ \\
Besar insentif & 0.278 \\
\hline
\end{tabular}

Ket: $*$ Nyata pada $\mathrm{p}<0,05 ; * *$ Nyata pada $\mathrm{p}<0,01$ 


\section{F. Simpulan}

Sebagian besar kader posyandu termasuk kategori usia produktif, pendidikan Sekolah Dasar dan Menengah, sebagai besar adalah berasal dari keluarga kecil yaitu $<4$, dan telah menikah dan umumnya tidak mempunyai balita yang diasuh. Ratarata lama menjadi kader > 36 bulan, motivasi kader adalah sebagai pengabdian pada masyarakat, Semua kader mendapatkan insentif dari pihak Puskesmas, umumnya memiliki dukungan posisitif dari suami dan

\section{G. Daftar Pustaka}

Abdul Rahman, 2008, Manajemen Sumber Daya Manusia, EGC, Yogyakarta.

Abdullah, 2003. Metodologi Riset Sosial dan Kesehatan, Rineka Cipta, Jakarta.

Arikunot, 2007. Manajemen Penelitian Rineka Cipta, Jakarta.

DEPKES RI, 1994. Pedoman Pembinaan Kader IPGK, Jakarta.

Hastono, 2007. Analisis Data. FKUI, Jakarta.

Heri Sutadi, dkk, 2006. Pengaruh Pemberian insentif Terhadap Keaktifan kader Posyandu di Wilayah Kerja Tuban Jatim, 2006. Skripsi.

Khotimah, 2002. Analisis Peranan Bidan Desa dalam Penggerakan

Sugeng hidayat. M, 2008. Posyandu, Perkembangan dan Masalah yang dihadapi. Majalah informasi dan Referensi Promosi Kesehatan. Depkes RI, Jakarta.

Widiastuti dan kristiani, 2006. FaktorFaktor yang Berhubungan dengan Pemanfaaatn Pelayanan Posyandu di Kota Denpasar Bali,Skripsi keluarga.

Adapun sebagai upaya untuk mempertahankan bahkan meningkatkan kinerja kader posyandu perlu dipertimbangkan pemberian insentif yang lebih layak. Insentif dapat diusahakan dari iuran para ibu yang berkunjung ke posyandu atau dengan mengalokasikan dari kas desa. Partisipasi kader dalam pelatihan perlu mendapatkan perhatian sebagai upaya untuk meningkatkan ketrampilan sekaligus kualitas kinerja kader dalam pengelolaan posyandu.

ader posyandu di Desa Wav Gubak Kecamatan Panjang Kota Bandar Lampung, Skripsi.

K-STATE, 2006. Confidential

Document: Annual Extension Agent PerformanceReview Kansan State University Agricultural Experiment Station and Cooperative Extenssion Service. 15 Jan 2012

Mathis, R.L .,Jackson JH, 2002. Human Reource Management. Alih Bahasa: Jakarta: Salemba Empat.

Rivai V, 2004. Manajemen Sumberdaya Manusia untuk Perusahaan, Jakarta:Raja Grafindo, Persada.

Saryono dan Meikawati, 2005. Posyandu dan Kegiatan Posyandu, Rineka Cipta, Jakarta 